\title{
STRATEGI PUSTAKAWAN DALAM MENINGKATKAN MINAT BACA PEMUSTAKA DI DINAS PERPUSTAKAAN DAN ARSIP KABUPATEN LOMBOK TENGAH
}

\author{
Iwin Ardyawin, Rohana, Nurwahida \\ Universitas Muhammadiyah Mataram \\ iwinardyawin@gmail.com
}

\begin{abstract}
ABSTRAK
Penelitian ini menggunakan metode pendekatan kualitatif deskriptif dengan teknik pengumpulan data melalui observasi, wawancara, dan dokumentasi. Hasil penelitian ini menunjukkan bahwa strategi yang dilakukan oleh pustakawan Dinas Perpustakaan dan Arsip Kabupaten Lombok Tengah dalam meningkatkan minat baca masyarakat telah diimplementasikan dalam berbagai bentuk kegiatan diantaranya yakni: 1) Meningkatkan saran dan prasarana. 2) Layanan Free Wifi. 3) Mengadakan lomba-lomba. 4) Melakukan kunjungan disetiap sekolah-sekolah yang ada di wilayah lombok tengah. 5) Memanfaatkan perpustakaan keliling pada saat CareFree Day di lapangan TASTURA setiap hari minggu. Untuk memperkenalkan perpustakaan kepada pemustaka. Adapun strategi yang dilakukan dalam meningkatkan minat baca adalah dengan meningkatkan literasi informasi pemustaka agar pemustaka tahu bagaimana mencari informasi, bagaimana memperoleh informasi, bagaimana memanfaatkan informasi dan ikut berpatisipasi dalam sosialisasi literasi informasi. Adapun kontribusi diharapkan dari penelitian ini adalah agar eksistensi Dinas Perpustakaan dan Arsip Kabupaten Lombok Tengah, selalu memberikan pelayanan yang maksimal dan menjadi pusat sumber belajar masyarakat yang dapat meningkatkan minat baca pemustaka yang berkunjung untuk memenuhi kebutuhan informasi.
\end{abstract}

Kata Kunci: Perpustakaan, Pustakawan, Minat Baca

\section{ABSTRACT}

This research uses descriptive qualitative approach method with data collection techniques through observation, interviews, and documentation. The results of this study indicate that the strategies carried out by the librarians of the Central Lombok District Library and Archives Office in increasing public reading interest implemented in various forms of activities including 1) Improving advice and infrastructure. 2) Free Wifi service. 3) Hold competitions. 4) Visit each school in the Central Lombok region. 5) Use the mobile library at CareFree Day in the TASTURA field every Sunday. To introduce libraries to users. The strategy carried out in increasing reading interest is by increasing the information literacy of readers so that readers know how to find information, how to obtain information, how to use information and participate in information literacy socialization. The contribution expected from this research is that the existence of the Central Lombok District Library and Archives Service always provides 
maximum service and becomes a center for community learning resources that can increase the reading interest of visitors who visit to meet information needs.

Keywords: Library, Librarian, Reading Interest

\section{PENDAHULUAN}

Perpustakaan harus berperan aktif dalam memberikan informasi kepada pemustaka sehingga dampak dari informasi yang update setiap waktu, dapat memberikan solusi terhadap apa yang menjadi permasalahan yang ada di tengah masyarakat disitulah perpustakaan harus memberikan peran yang sangat penting sebagai solusi dari apa yang menjadi permasalahan tersebut. Perpustakaan yang berada di tengah-tengah masyarakat harus mampu memberikan perannya sebagai penyedia informasi untuk memenuhi kebutuhan pemustaka. Perpustakaan juga dituntut untuk dapat menyediakan pelayanan yang maksimal secara tepat dan cepat sesuai masing-masing kebutuhan pemustaka.

Dinamika media informasi yang berkembang, mempengaruhi pula perkembangan minat masyarakat dalam mengakses informasi jika dahulu buku dan catatan-catatan manual menjadi sumber baca, maka kini sudah mengarah pada data online yang bisa diakses di semua tempat dan setiap saat. Perpustakaan merupakan suatu lembaga atau tempat dimana masyarakat umum dapat melakukan berbagai macam kegiatan yang bersifat menambah pengetahuan seperti meminjam buku, membaca ataupun mencari berbagai macam informasi yang ingin diketahui. Pelayanan merupakan ujung tombak jasa perpustakaan, karena bagian inilah yang pertama berhubungan dengan masyarakat pengguna yang ada di perpustakaan, karena jasa perpustakaan baru terasa manfaatnya bila informasi yang diberikan perpustakaan sesuai dengan kebutuhan masyarakat pengguna.

Fakta sudah terlalu jelas mengatakan bahwa wajah sebuah bangsa dapat dilihat dari wajah perpustakaannya dan kemajuan sebuah bangsa dapat dilihat dari tingkat minat bacanya. Baik secara langsung maupun tidak langsung kebiasaan membaca menjadi salah satu indicator kualitas sekolah bahkan secara nasional sangat menentukan tinggi rendahnya index pembangunan manusia atau human development index (HDI, dan tinggi rendahnya HDI menentukan kualitas bangsa. Sejarah dari 
kemajuan negara-negara di dunia, seperti

Jepang, Amerika, Korea, dan negara-negara lainnya berawal dari ketekunannya membaca. Keberhasilan perpustakaan sangat ditentukan oleh pustakawan, meskipun perpustakaan memiliki anggaran luar biasa, dilengkapi dengan teknologi yang canggih, dipercantik dengan layanan sangat excellent dan banyaknya layanan terbarukan. Jika tanpa andil pustakawan dengan kapasitas maupun kredibilitas maka bisa dijaminkan roda perpustakaan tidak akan optimal karena antara fasilitas dan sumber daya manusia dua hal saling melengkapi. Bilamana perpustakaan tanpa kehadiran pustakawan maka ibarat gudang yang hanya sebagai pajangan atau seonggok buku.

Minat baca muncul ketika seseorang telah memiliki kemampuan membaca sedangkan budaya baca terpelihara bila bahan baca terjangkau dan jenis yang tersedia sesuai dengan minat pembacanya. Budaya baca dapat terwujud baik karena keinginan pribadi maupun bentukan lingkungan yang kondusif. Pemustakapun lebih memilih untuk searcing informasi di internet, sehingga keberadaan perpustakaan di tengah masyarakat menjadi terabaikan karena informasi yang mereka dapatkan belum terpenuhi. Dalam meningkatkan kebiasaan membaca pemustaka perlu adanya fasilitas dan koleksi perpustakaan yang dapat memenuhi kebutuhan informasi pemustaka. Perpustakaan harus dapat melihat kebutuhan pemustaka sehingga dapat dengan leluasa memilih jenis bacaan mana saja yang dibutuhkan. Perpustakaan umum memiliki koleksi yang sangat beragam dan kalangan pemustaka yang sangat luas, mulai dari anak-anak sampai orang tua yang berusia lanjut dapat menjadi anggota perpustakaan umum ini. Pemustaka pun terdiri dari berbagai macam propesi atau berbagai macam pendidikan, untuk itu kebutuhan informasi yang dicarinya juga sangat beragam dan berbeda-beda. Ini merupakan sebuah tantangan bagi Dinas Perpustakaan dan Arsip Kabupaten Lombok Tengah, untuk dapat memfasilitasi dan melengkapi semua jenis koleksi dan informasi yang dibutuhkan oleh pemustaka untuk meningkatkan minat baca semua lapisan masyarakat. Sehingga penelitian ini difokuskan pada bagaimana strategi yang dilakukan pustakawan dalam meningkatkan minat baca pemustaka di Dinas Perpustakaan dan Arsip Kabupaten Lombok Tengah. Berdasarkan uraian di atas, maka penulis berminat untuk meneliti dengan rumusan masalah sebagai berikut:

1) Bagaimana strategi yang dilakukan pustakawan dalam meningkatkan minat 
baca pemustaka di Dinas Perpustakaan dan Arsip Kabupaten Lombok Tengah?

2) Bagaimana kendala-kendala minat baca pemustaka di Dinas Perpustakaan dan Arsip Kabupaten Lombok Tengah?

\section{LANDASAN TEORI}

Sutarno NS, 2003 dalam Laksmi menjelaskan bahwa Munculnya minat baca seseorang dipicu oleh berbagai faktor, sesuai karakter dan kondisi yang bersangkutan. Secara umum, dapat disebutkan di sini bahwa faktor-faktor tersebut adalah: rasa ingin tahu yang tinggi atas fakta, teori, prinsip, pengetahuan, dan informasi. Faktor kedua adalah keadaan lingkungan fisik yang memadai, misalnya adanya bahan bacaan yang menarik, berkualitas, dan yang dapat memenuhi kebutuhan mereka, selain itu faktor lingkungan sosial juga memiliki peran yang besar, misalnya lingkungan yang kondusif, seperti keluarga yang sejahtera, tenang dan memberi teladan yang baik, dapat memicu seorang untuk memanfaatkan waktunya bersama buku. Selanjutnya, faktor keingintahuan akan informasi dan prinsip bahwa membaca merupakan kebutuhan rohani, merupakan pemicu yang tidak kalah penting.

\section{Strategi}

Strategi merupakan suatu perencanaan pembuatan metode untuk berkompetisi dalam pasar, memuat taktik yang digunakan untuk menjalankan aktivitas dan tujuan yang sudah direncanakan, dengan mempertimbangkan organisasi tetap perlu menyesuaikan diri dengan kondisi persaingan. Untuk menyusun strategi yang baik, perlu dilakukan analisis SWOT, kepanjangan dari strengths, weaknesses, opportunities dan threats, baik dari lingkungan internal maupun eksternal. Penciptaan strategi selalu mempertimbangkan nilai-nilai manajemen dan tanggungjawab sosial.

\section{Minat Baca}

Perpustakaan memiliki peranan yang signifikan untuk mendukung gemar membaca dan meningkatkan literasi informasi, juga untuk mengembangkan pemustaka agar supaya dapat belajar dengan didukung oleh perpustakaan sebagai pusat sumber belajar. Minat baca merupakan salah satu unsur yang mempengaruhi prestasi belajar siswa dan perlu ditingkatkan. Dengan membaca dapat meningkatkan prestasi dan kreativitas siswa yang sangat berguna untuk siswa tersebut.Semakin sering membaca maka semakin banyak pula 
informasi dan ilmu pengetahuan yang

didapat dari membaca. Dengan ilmu yang dimiliki akan membuat siswa menjadi sumber daya manusia yang unngul dan bermanfaat di kehidupan nanti.

Pentingnya membaca juga di tegaskan dalam Islam. Dalam Islam, keyakinan tauhid yang menjadi pusat ajarannya, bahkan dimulai dengan aktivitas membaca: iqro. Membaca adalah pintu pertama kearah keyakinan terhadap Tuhan dan ajaran-ajaranNya yang lain. Tidak ada keyakinan tanpa membaca. Tidak ada pengetahuan tanpa membaca. Akan tetapi, realitas dari minat baca itu sendiri masih sangat rendah. Budaya membaca masih sangat jauh.

Hal ini sejalan dengan pendapat yang dikemukakan oleh Oemar Hamalik (1978: 217), bahwa motivasi dapat dikelompokkan ke dalam motivasi intrinsic dan motivasi ekstrinsik (eksternal).

1) Motivasi Internal

Motivasi internal adalah motivasi yang timbul dari dalam diri manusia, seperti keinginan untuk mendapatkan keterampilan dan mengembangkan sikap untuk berhasil. Hal-hal penting yang dapat menimbulkan motivasi internal di antaranya adalah sebagai berikut:

\section{a) Kebutuhan}

Adanya kebutuhan maka seorang didorong untuk membaca.Misalnya seorang anak yang ingin mengetahui isi cerita sebuah komik maka keinginan tersebut menjadi daya dorong yang kuat bagi anak untuk membaca.Apabila dia telah membaca maka kebutuhannya untuk mengetahui isi cerita komik tersebut telah terpenuhi.

b) Pengetahuan tentang kemajuan sendiri

Apabila seseorang mengetahui hasilhasil atau prestasinya sendiri dari membaca maka ia akan terdorong untuk membaca lebih banyak lagi. Misalnya anak yang telah membaca sebuah buku dan ia dapat menuangkan kembali kata-katanya sendiri, kemudian dimuat di majalah anak-anak atau lembar anak pada suatu surat kabar maka akan mendorong anak untuk membaca lebih banyak lagi. Sebaliknya, apabila seorang anak memperoleh kesulitan dalam mencerna atau memahami isi suatu buku maka ia akan merasa enggan untuk membaca buku yang serupa.

c) Aspirasi atau cita-cita

Bagi seorang anak kecil, mungkin belum mempunyai cita-cita, ataupun bila memiliki cita-cita, cita-citanya barangkali masih sangat labil atau sangat sederhana. 
Sebaliknya, bagi anak yang sudah remaja, cita-cita itu akan menjadi lebih jelas dan tegas, misalnya cita-cita menjadi dokter, insinyur, militer, dan sebagainya. Cita-cita tersebut akan menjadi pendorong bagi seseorang untuk belajar, karena dengan belajar lebih banyak, ia akan dapat mencapai cita-citanya. Dengan kemauan belajar yang keras, ia akan terdorong untuk membaca lebih banyak pula.

\section{2) Faktor-faktor Internal}

Faktor-faktor internal yang mempengaruhi pembinaan minat baca di dalam perpustakaan, antara lain sebagai berikut:

a) Kurangnya tenaga pengelola perpustakaan

Kurangnya jumlah tenaga pengelola perpustakaan, baik yang berpredikat pustakawan yang berpendidikan jurusan ilmu perpustakaan maupun structural masih jauh dari yang diharapkan.Oleh karena itu, kebanyakan mereka kurang menaruh perhatian terhadap pembinaan minat baca yang merupakan salah satu tugas dan tanggung jawab yang harus dilaksanakan.

b) Kurangnya dana pembinaan minat baca

$$
\text { Meskipun para pengelola }
$$

perpustakaan menyadari bahwa pembinaan minat baca merupakan salah satu tugas dan tanggung jawab, namun banyak di antaranya yang terbentur pada keterbatasan dana. Biaya yang dibutuhkan untuk pembinaan minat baca cukup besar, antara lain untuk menambah koleksi bahan pustaka yang sesuai dengan kebutuhan pengguna perpustakaan, untuk pencetakan brosur-brosur, poster-poster, dan yang sejenisnya. Hal itu dilakukan untuk mengadakan berbagai kegiatan peningkatan minat baca.Selain itu, dapat juga dengan menyelenggarakan pameran, mengadakan berbagai lomba, menyelenggarakan seminar atau ceramah yang dapat mendorong setiap orang untuk memiliki minat baca.

c) Terbatasnya bahan pustaka

Keterbatasan bahan pustaka ini bukan hanya sekedar jumlah dan variasinya yang belum memenuhi kebutuhan pengguna jasa perpustakaan, tetapi juga terbatasnya mutu bahan pustaka yang dilayankan di perpustakaan. Karena dana yang terbatas, sulit bagi perpustakaan untuk menyediakan bahan pustaka yang bermutu yang dibutuhkan masyarakat. 

d) Kurangnya variasi jenis layanan perpustakaan

Kurangnya variasi pemberian layanan peminjaman seperti layanan refrensi, layanan pemutaran film, layanan bercerita, layanan penelusuran informasi, dan sebagian banyak yang belum disajikan.

e) Terbatasnya ruang perpustakaan

$$
\text { Banyak perpustakaan yang }
$$
ruangannya belum memiliki ruang baca, ruang pemutaran film, layanan bercerita, layanan penelusuran informasi dan sebagainya.

f) Terbatasnya perabot dan peralatan perpustakaan

Banyak perpustakaan yang belum memiliki peralatan yang dapat mendukung pembinaan minat baca, seperti tersedianya berbagai macam proyektor (proyektor film, proyektor untuk slide/film stripe ataupun proyektor untuk transparansi), mesin fotocopi, mesin pembaca bentuk mikro (microreader), dan sebagainya.

g) Kurangnya lokasi perpustakaan

Banyak perpustakaan yang kurang menarik pengunjung dikarenakan letaknya yang tidak strategis.Lokasi perpustakaan banyak yang diletakkan di bagian belakang gedung sehingga banyak yang segan mendatanginya.

h) Kurangnya pemasyarakatan perpustakaan

Kurangnya promosi atau pemasyarakatan menyebabkan tidak banyak anggota masyarakat memanfaatkan jasa layanan perpustakaan. Akibatnya, masyarakat kurang tertarik pada perpustakaan.

\section{3) Motivasi eksternal}

Motivasi ekstrinsik atau motivasi eksternal adalah motivasi yang disebabkan oleh faktor-faktor di luar situasi manusia, seperti lingkungan keluarga dan lingkungan sekolah. Hal-hal yang dapat menimbulkan motivasi eksternal adalah sebagai berikut:
a) Hadiah

Hadiah adalah alat yang representatif dan bersifat positif.Hadiah telah menjadi alat motivasi bagi seseorang.Hadiah telah menjadikan seseorang terdorong untuk melakukan sesuatu lebih giat lagi. Bagi anak-anak yang memperoleh nilai baik akibat banyak membaca, akan mendorongnya untuk membaca lebih banyak lagi untuk kemudian memperoleh prestasi yang lebih baik lagi. 
b) Hukuman

Hukuman dapat juga menjadi alat motivasi untuk mempergiat seseorang membaca. Seseorang yang mendapat hukuman karena kelalaian tidak mengerjakan tugas membaca maka ia akan berusaha untuk memenuhi tugas membaca agar terhindar bahaya hukuman yang mungkin menimpa lagi.

c) Persaingan atau kompetisi

Persaingan merupakan dorongan untuk memperoleh kedudukan atau penghargaan. Kompetisi telah menjadi daya pendorong bagi seseorang untuk membaca lebih banyak.

4) Faktor-faktor Eksternal

Faktor-faktor eksternal adalah faktorfaktor yang berada di luar perpustakaan, namun mempengaruhi pembinaan minat baca yang menjadi salah satu tugas dan tanggung jawab perpustakaan. Faktor-faktor tersebut adalah sebagai berikut:

a) Kurangnya partisipasi pihak-pihakyang terkait dengan pembinaan minat baca.

b) Kurang terbinanya jaringan kerjasama pembinaan minat baca antar perpustakaan.

c) Sektor swasta belum banyak menunjang pembinaan minat baca. d) Belum semua penerbit berpatisipasi dalam pembinaan minat baca.

e) Belum semua penulis berpatisipasi dalam pembinaan minat baca.

\section{METODE PENELITIAN}

\section{a. Analisis Data}

$$
\begin{aligned}
& \text { Analisis data yang dilakukan } \\
& \text { dalam penelitian ini adalah Kualitatif } \\
& \text { Deskriptif dengan cara menggambarkan } \\
& \text { sesungguhnya apa yang terjadi dilokasi } \\
& \text { penelitian dengan menggunakan teknik } \\
& \text { wawancara langsung kepada pustakawan } \\
& \text { yang mendapatkan tugas untuk }
\end{aligned}
$$
mengembangkan minat baca pemustaka Dalam hal ini semua data yang diperoleh penelitian akan dianalisis dan diungkapkan dengan kata-kata menjadi landasan dalam mendeskripsikan strategi yang dilakukan pustakawan dalam meningkatkan minat baca pemustaka di Dinas Perpustakaan dan Arsip Kabupaten Lombok Tengah.

\section{b. Metode Pengumpulan Data}

Ada beberapa metode yang dilakukan untuk mengumpulkan data dalam penelitian ini adalah:

1. Observasi 
Menurut Nasution, sebagaimana yang dikutip oleh Sugiyono, Observasi adalah dasar dari ilmu pengetahuan. Penelitian ini hanya dapat dilaporkan menampilkan atau menunjukkan data, yaitu fakta yang diperoleh melalui observasi. Oleh karena itu, observasi yang dilakukan peneliti untuk mendapatkan data-data terkait dengan pokok-pokok masalah di atas.

\section{Wawancara}

adalah bentuk komunikasi langsung antara peneliti dan responden. Komunikasi berlangsung dalam bentuk tanya-jawab dalam hubungan tatap muka, sehingga gerak dan mimik responden merupakan pola media yang melengkapi kata-kata secara verbal.

\section{Dokumentasi}

Dalam hal ini peneliti akan memperlihatkan dokumen-dokumen yang relevan atau terkait dengan strategi pengelola perpustakaan dalam meningkatkan minat baca pemustaka di Dinas Perpustakaan dan Arsip Kabupaten Lombok Tengah. c. PEMBAHASAN

1) Bagaimana strategi yang dilakukan pengelola perpustakaan dalam meningkatkan minat baca pemustaka di Dinas Perpustakaan dan Arsip Kabupaten Lombok Tengah?

Dinas Perpustakaan dan Arsip Kabupaten Lombok Tengah dalam meningkatkan minat baca terhadap pemustaka melakukan berbagai macam starategi salah satunya adalah sebagai berikut:

Narasumber Dari Hasil Wawancara dengan: H. A. Ajim (Sebagai wakil Kepala Perpustakaan)

Strategi Badan Perpustakaan dan Arsip Kabupaten Lombok Tengah untuk Menigkatkan strategi minat baca adalah dengan cara mengalokasikan gedung dan ruangan perpustakaan yang sebelumnya hanya tersedia meja kecil untuk tempat membaca dan sekarang berubah menjadi banyak meja-meja baca, rak-rak buku yang rapi dan lengkap serta adanya wifi untuk menunjang kebutuhan pemustaka agar tidak bosan berada di dalam perpustakaan dan juga di sertai dengan adanya CCTV agar pemustaka tidak takut akan barang bawaan yang hilang dan lain sebagainya. Perpustakaan juga 
membuat sosialisasi ke masyarakat dengan tujuan menghilangkan anggapan-anggapan pemustaka yang di mana kebanyakan pemustaka berpikir bahwa perpustakaan adalah gudang buku dan sepi dari pengunjung maka dari itu strategi perpustakaan untuk menigkatkan strategi minat baca supaya datang ke perpustakaan degan cara:

- Peningkatan saranan dan prasarana di perpustakaan tersebut

- Menata ulang rak-rak buku supaya lebih nyaman maka perpustakaan melakukan perbaharuan

- Memberikan layana free wifi internet

- Mengadakan aspek hiburan untuk menyenagkan pengunjung.

Tidak hanya itu saja strategi dinas perpustakaan dan arsip kabupaten Lombok Tengah dalam meningkatkan minat baca adalah dengan cara melakukan kunjungan di setiap Sekolah-sekolah, Desa-desa, Perpustakaan keliling, membuka stand di alun-alun TASTURA dan mengadakan lomba-lomba diantaranya:

- Menggambar

- Mewarnai

- Standup comedy

- Pidato bahasa inggris

\section{- Bercerita}

Kunjungan ke setiap sekolah-sekolah dengan adanya strategi ini mampu menumbuhkan minat baca siswa-siswi yang ada di sekolah tersebut, mengunjungi setiap desa-desa yang jauh dari kota (pelosok) mensosialisasikan tentang pentingnya minat baca bagi masyarakat dan dari sosialisasi ini mampu memberi pemahaman kepada masyarakat untuk menumbuh kembangkan minat baca masyarakat tersebut dan inilah tujuan dari perpustakaan keliling untuk mengunjungi desa-desa yang kurang akan minat bacanyaa, membuka stand di alunalun TASTURA setiap minggu pagi dan membuat forum atau kelompok minat baca dari kalangan anak-anak sampai dewasa itu rutin di lakukan setiap minggu pagi karena setiap minggu jalanan Alun-alun TASTURA di tutup untuk Care freeday sehingga banyak masyarakat yang berkunjung ke sana, Dinas Perpustakaan dan Asrip Kabupaten Lombok Tengah juga mengadakan lomba-lomba seperti yang tertera di atas dan salah satu lomba yaitu lomba bercerita mendapatkan juara satu sampai tingkat provinsi dan ini sangat membanggakan bagi Dinas Perpustakaan dan Asrip Kabupaten Lombok Tengah. 
Pengguna atau pengunjung yang

datang ke perpustakaan dari kalangan Pelajar di anataranya dari tingkat paling rendah taman Kanak-kanak, Sekolah Dasar, SMP, SMA, MAHASIAWA. Pegawai dan Masyarakat umum. Tetapi yang lebih sering berkunjung adalah kalangan pelajar yang mencari buku atau sekedar mengerjakan tugas sekolah di perpustakaan dan memanfaatkan fasilitas wifi gratis, karena perpustakaan tidak memberikan batas untuk menggunakan WIFI yang di pakai pemustaka, oleh sebab itu pengunjung perpustakaan tidak bosan dan ingin berlamalama di perpustakaan.

\section{2) Bagaimana kendala-kendala minat baca pemustaka di Dinas Perpustakaan dan Arsip Kabupaten}

\section{Lombok Tengah?}

Hambatan yang terjadi ketika pengelola perpustakaan melakukan kegiatan-kegiatan yang berhubungan dengan minat baca sebagai berikut:

1. Dari segi anggaran yang masih minim sehingga kegiatan pembinaan minat baca masih kurang maksimal.

2. Masih belum banyak yang mengetahui tentang literasi informasi.

3. Masih kurangnya SDM.

4. Perlu adanya sosialisasi yang intensif terhadap pembinaan minat baca.
Maka dari itu agar perpustakaan dapat dimanfaatkan secara maksimal, minat dan kebiasaan membaca serta meningkatkan literasi informasi pemustaka perlu ditingkatkan dan ditumbuh kembangkan. Keberadaan sebuah perpustakaan umum merupakan suatu hal yang wajib ada. Perpustakaan merupakan gudangnya ilmu dan informasi bacaan, baik yang berkaitan dengan dunia pendidikan maupun pengetahuan umum sehingga keberadaan perpustakaan di tengah masyarakat diharapkan dapat memudahkan masyarakat sebagai pemustaka dalam mencari referensi atau rujukan. Selain itu juga dapat menanamkan kebiasaan membaca sejak dini.

\section{KESIMPULAN}

Dinas Perpustakaan dan Arsip Kabupaten Lombok Tengah terus menerus melakukan pembenahan mulai dari SDM, Fasilitas, Komunikasi yang efektif antara pustakawan dengan pemustaka serta informasi-informasi yang dapat meningkatkan pemustaka untuk datang memanfaatkan perpustakaan sehingga untuk menumbuhkan minat baca dikalangan masyarakat dapat dilakukan dengan kegiatan seperti yang telah dijelaskan sebelumnya yaitu promosi perpustakaan dan meningkatkan literasi informasi pemustaka. 
Sementara ini hanya ada dua program yang sedang dilakukan oleh pihak balai layanan perpustakaan dalam melalukan strategi meningkatkan minat baca masyarakatdan berperan aktif dalam memberikan informasi kepada pemustaka sehingga dampak dari informasi yang update setiap waktu.

\section{DAFTAR PUSTAKA}

Laksmi. (2006). Tinjauan Kultural Terhadap Kepustakawanan: inspirasi dari sebuah karya Umberto Eco. Depok: Fakultas Ilmu Pengetahuan Budaya.

Purwono. (2013). Profesi Pustakawan Menghadapi Tantangan Perubahan. Yogyakarta: Graha Ilmu.

Saleh, Adul Rahman. (2011). Percikan Pemikiran di Bidang Kepustakawanan. Jakarta: Sagung Seto.

Suherman. (2009). Perpustakaan Sebagai Jantung Sekolah. Bandung: MQS Publishing.
Sudarsana, Undang. (2010). Materi pokok pembinaan minat baca. Jakarta: Universitas Terbuka.

Sugiyono. (2010). Metode Penelitian Kuantitatif Kualitatif dan R\&D. Bandung: Alfabeta.

Suwarno, Wiji. (2016). Library Life Style (trend dan Ide kepustakawanan) Yogyakarta: Lembaga Ladang Kata.

Touku Umar. (2013). Strategi Pengelola Perpustakaan dalam Meningkatkan Minat Baca Masyarakat sebagai Pemustaka di Badan Perpustakaan dan Arsip Daerah Provinsi Sulawesi Selatan. Program Studi Interdisciplinary Islamic Studies Konsentrasi Ilmu Perpustakaan dan Informasi, Pascasarjana.

Makmur, Testiani. (2015). Budaya Kerja Pustakawan di Era Digitalisasi; Perspektif Organisasi, Relasi dan Individu. Yogyakarta: Graha Ilmu.

W. Gulo. (2002). Metodologi Penelitian. Jakarta: PT. Grasindo. 